\title{
Empowering civil society through educating about responsible research and innovation
}

\author{
Marta Majorek ${ }^{1, *}$ and Marta du Vall $^{2}$ \\ ${ }^{1}$ Andrzej Frycz Modrzewski Krakow University, Herlinga - Grudzińskiego 1, Kraków 30-705, \\ Poland \\ ${ }^{2}$ Andrzej Frycz Modrzewski Krakow University, Herlinga - Grudzińskiego 1, Kraków 30-705, \\ Poland
}

\begin{abstract}
Number of factors may be indicated that can negatively affect the willingness of third sector actors and citizens to get involved with research and innovation policy. It is worth referring to these factors as barriers to societal engagement. Six key barriers can be identified: lack of knowledge and skills, lack of relevance, lack of impact, lack of trust and critical views of others, lack of time and finances, and lack of legitimacy. The main purpose of this article is to present some policies and practice options that can help to overcome these barriers. The main focus will be on solving the lack of knowledge and skills of social actors. In this context, the fact that citizens and third sector actors may perceive an engagement process as not relevant to their own interests, concerns, and goals may be indicated as the main cause for their non-involvement. Citizens and third sector actors may refrain from engagement when they fear they lack the necessary knowledge and skills to engage in research or in research and innovation policy. They may also be reluctant to participate when they do not have the basic understanding of science and scientific working methods. The article will propose an overview of policies and activities that can effectively overcome the indicated barriers to engagement.
\end{abstract}

Keywords. Civil society, education, RRI, societal engagement

\section{Introduction}

The Responsible Research and Innovation tool was created to build effective cooperation between science and society in order to acquire new talents for research and innovation and to combine scientific excellence with social awareness and responsibility. Contribution to solving European social problems identified in Horizon 2020, building capacity and developing innovative methods for inclusion of science into the society are some of its main goals. Therefore, learning will become more attractive (especially for young people), the interest of the society in innovation will increase and further research and innovation activities will be possible.

* Corresponding author's e-mail: mmajorek@afm.edu.pl 
As a part of the program, all social actors (scientists, citizens, policy makers, businesses, third sector organizations, etc.) have the opportunity to cooperate throughout the research and innovation process in order to adapt both the process and its results to values, needs and expectations of the European society to a greater extent. The RRI aims to ensure cooperation between social actors throughout the entire research and innovation process. In general terms, the RRI stands for anticipating and evaluating potential social effects and expectations in relation to research and innovation [1].

In practice, responsible research and innovation consists of the design and implementation of research and innovation policy which will broadly involve society in its research and innovation activities, increase access to scientific research results, ensure gender equality, both in the research process and the scope of research being carried out, consider the ethical dimension, promote formal and informal education in science education. The basic idea lying under the RRI is that given the significant impact that ICT innovation has on our world, the whole society should be involved in the process. This means that research and innovation projects come from a closed world of experts in "hard science", opening up to social sciences and humanities, as well as citizens and civil society organizations which can offer various perspectives and creativity as well as foster some more socially relevant outcomes. Another important dimension of the RRI is the development of open access, promotion of science education, care for gender equality and ethical standards [2]. In this context, it is worth considering the role of the Responsible Research and Innovation in promoting attitudes of social involvement, and in particular the role of education in development of attitudes which are open to cooperation and joint action in the field of science and innovation. In the first place, the issues related to the problem of no social involvement and its effects that can currently be noticed in contemporary societies will be discussed in a comprehensive way. Afterwards, the solutions offered by the tools which are created as part of the project of responsible research and innovation with particular emphasis on the sphere of knowledge and education will be indicated. Particular emphasis in this respect will be placed on the social actors, who bear the burden of involvement in social innovation processes, and whose participation in projects aimed at creating and implementing modern solutions in the social area is often insufficient.

\section{From civil society to global civil society}

The very idea of civil society as such is an issue considered by the philosophy of politics almost from the very beginning of reflection on the idea of state and citizenship. It consists a number of issues which, among others, allow to categorize the relations between the state, the authorities and citizens. Its function is to establish relations within the society or to present a way of an individual's life in order to become a citizen. So far, the research has focused mainly on the idea of civil society as a local mechanism of action in the area of relations between the state and its citizens [3]. It is worth pointing to one, indispensable element based on which a civil society is formed. It is the acceptance and absolute respect for certain norms and values with clearly liberal roots. These norms include, above all, tolerance, mutual respect and trust, pluralism, as well as a sense of identification and solidarity with the community, responsibility for its fate, and readiness to actively work for its well-being and in its defense [4].

Along with the dynamic development of the new information and communication technologies, the perception of a civil society has also deeply changed. There was a need to create a new theoretical framework, for the sake of changing conditions. It seems, therefore, that the most adequate statement is the attempted definition of a civil society at the global level as a network of interrelated and mutually dependent social organizations, what is related to their activities carried out beyond the closest local surroundings, intended for (as 
grand as it sounds) improvement of the overall situation of the organizations trying to implement and respect human rights, improve working conditions, and take care of the environmental protection etc. The global civil society is a creation that transcends national borders and states, at the same time being rooted in them and this rooting does not renounce. It is a collection of individuals, organizations, sometimes companies, which, while operating under local laws and conditions, deal with issues of broadly understood globalization in economic, cultural and social dimensions. However, the interrelations and interdependencies among these individuals or organizations which are created at a level exceeding geographical, ideological, and cultural boundaries are the key here [5]. Due to social, cultural and economic changes caused by the expansion of new technologies, the very construction of the civil society has changed, which nowadays tend to detach from its global connotations. Therefore, the European Union programs and tools created for the purpose of connecting citizens with the area of science and innovation and strengthening their involvement in the process of developing and implementing modern solutions, must take into account the transnational aspect and work to strengthen the supra-social ties and structures. It is necessary to consider the importance of multicultural approaches while creating such tools. Development of universal tools and processes is not an easy task and it requires reflection on the shape of contemporary, diversified social recipients.

\section{Meaning and significance of social engagement}

Nowadays, we observe a significant growth of interest in publicly engaged and participatory research. Discussions devoted to engagement, the democratization of knowledge generation and societal participation in decision making are, of course, not a new subject of interest. As Nick Mahony and Hilde C. Stephansen highlighted, this growing body of literature on public engagement with socio-cultural research is currently missing an analysis that encompasses developments in public engagement and participation beyond academia based on contemporary practice. As is well-documented, recent years have been characterized by a 'participatory turn' in a number of domains, including higher education, science and technology, environment, urban regeneration, arts and policy making [6].

The main question arises - what the societal engagement means? The simplest answer is that this is the ability to work constructively within and between social groups to create more resilient and sustainable communities. The indicated definition appears to be highly simplified, but it contains numerous meanings. Social involvement may be manifested in many activities, but nowadays, we deal with its decreasing extent. The inability to see the world from the vantage point of others is a key factor behind both the local and civil conflict. It can also lead to less violent but equally harmful problems of alienation, marginalization and exclusion. We develop our identity by comparing ourselves to like and unlike groups, but this can lead to jumping at assumptions and stereotyping as people struggle to make sense of who they are. Understanding how identity categories are created and how labels can be attached to determine people as insiders or outsiders is important in developing more resilient and sustainable communities. Although learners may have covered the notion of citizenship at school, rarely does the citizenship education include any personal reflection or experiential learning and it may not implement any democratic classroom practices. Learners talk about differences and equalities in a multicultural world, but with the limited direct experience of the range of people that make up any community, they may not have the emotional literacy or the skills to deal with it. Building equal relationships and finding some common grounds with those individuals, when this is not immediately obvious, requires a certain level of some personal confidence which the learners can only develop for themselves [7]. 
Merrifield, in the research carried out on 'learning citizenship', concluded that 'civic education framed in terms of knowledge and perhaps values but without an experiential component has little impact on behavior' [8]. The popular theory of Putnam's social capital is widely adopted to aid in the analysis of social engagement. His extensive study of American society at the end of the 20th century identified a growing sense of fear and isolation and the demise of trust, support and belonging. He sees the development of social networks as important to the well-being of individuals and groups and differentiates between the notion of bonding and bridging the social capital. Bonding involves reciprocal relationships between known groups that grow out of doing things for people you know will do things for you in return. But by focusing on similarities and facilitating inclusion, this can reinforce divisions between identity groups. Bridging the social capital, on the other hand, involves reciprocal relationships between unlike groups, doing things for people you do not necessarily know, and a more generalized reciprocity. It stems from the belief that borader contribution to a trustful and giving society will eventually benefit us all [9]. The social capital is a concept often defined through the prism of social relations and benefits gained by a local community, within which it is developed.

The main element creating the social capital is trust, which is the basis for development to strengthen local networks. Social cooperation is another key term for the development of social capital., Development of the social capital is important for non-governmental organizations and it coincides with their mission and goals. It allows to use the existing networks of relationships for cooperation, making contacts, implementing plans in a new group, as it makes it easier to establish contacts. This improves the resources and strengthens the efficiency of functioning. In addition, greater public confidence is also reflected in the level of intersectoral cooperation with public administration and business, where the culture of cooperation and prejudice towards NGOs pose a problem [10].

\section{Involving social actors in creation of science and innovation policy}

Engaging societal actors in the research and innovation (R\&I) activities is beneficial for the researchers as well as the public in general. Societal engagement can be pursued for both democratic (citizens having a say on research agendas) and instrumental reasons (more appropriate research results by including societal knowledge, ideas and capacities; higher awareness of science and technology with citizens) [11]. There are specific groups of actors, which should be involved in science and innovation policy: CSOs (such as patient organizations or environmental NGOs) and citizens, especially those with regard to democratic motives [12]. The Engage2020 program identified 6 forms, or dimensions, of policy and activity support, which are relevant to encouraging public engagement in science and research and provided its recommendations based on the following categories: Rules and regulations. This is the most formal effort to integrate public engagement in the R\&I policy making and practice; Funding and other incentives which constitute a very effective lever to direct research activities; Promotion which is next to the strong "formal" incentives. Some "soft" promotion activities are proposed as they have the potential to raise interest in engagement in innovation processes on a broad and continuing basis. However, from the point of view of this subject of analysis, the most crucial aspects are among others teaching and training. It is especially demanding to conduct an engagement process and to get relevant results out of it. Even if a participative process was conducted in the best methodical manner, it is not certain whether the results of the process would be used and kept by the political institutions which initiated the participation process. In order to introduce the processes into the Research \& Innovation actions undertaken by the European Commission, of national or regional R\&I structures, and to have the involved 
administrative bodies employed the results, it is especially important to directly address and educate various groups of people which are a part of the public engagement process. Various specialists can be involved in this process, from EC administrators and advisors to national policy-makers and government experts, scientists, and other public actors. Successful integration of engagement requires not only theoretical and methodical knowledge about diverse forms and methods of participation. It also demands certain "participative" competences, e.g. discursive, analytical, or moderation skills, which should be trained. In our understanding, the RRI requires research to be anticipatory, inclusive, and reflexive. It should be also responsive, and here is a vital role of citizens, stakeholders and users to be played in embodying the RRI vision. Today, tens of thousands of Europeans are involved in participatory processes every year, and institutions see the benefits. Most participants and creators of RRI tools believe that the future of the European science and technology field depends on proper implementation of this concept. Strong engagement from European citizens, stakeholders and users is a crucial part of this emerging landscape. Regardless of what role any individual plays in the research and innovation in the future, they will definitely need to consider how the social actors can work to address the societal challenges [13].

\section{More knowledge - more innovation and engagement}

Undoubtedly, we have a lot to do within the area of innovation. In the Global Innovation Index 2015 rank, which determined the level of innovativeness of individual countries, Poland holds the 46th place in the world, out of 141 classified countries [14]. Why such a weak result? Well, the reasons should be seen in the still unfavorable market situation and in the lack of comprehensive support for innovative investments. An investor will provide funds to implement a specific idea if the chances of success are sensibly calculated. If the risk does not bring any profits because the environment is not conducive to its taking, and the reimbursement of costs incurred takes too long or is uncertain, no one will fund even the most promising investment. This is one side of the coin. The second one is actually education. However, we should go a little further here: the university level complements the educational path, which starts much earlier and is unfortunately not a success in our case [15]. We do not teach children and youth how to cooperate, we do not show that it is worth risking. Instead, we instill a lot of doubt in them, the fear of public ridicule, and patterns of thinking and acting. This happens long before the stage of choosing between a humanist and a strict discipline. Yet another issue is a completely false division, placing the humanists overloaded with the impractical knowledge on one side of the reconstructive barricades, while the innovative researchers and engineers remain on the other. This should not be and is not present in any of the countries in the top places of the Global Innovation Index [16]. Everyone should create innovations, not just scientists and engineers. Hence, involvement of other sectors is so significant, not directly related to the sphere of research and innovation

When it comes to research and research and innovation policy, citizens and third sector actors may fear they lack the necessary knowledge and skills to engage. This inevitably leads to a situation of fear of involvement. Due to the lack of knowledge about science and scientific topics citizens can refrain from participation when they have no basic understanding of science and scientific working methods. They may also be reluctant to participate when they lack knowledge about a given scientific topic. The topic may have not been of interest to them so far or it may be that there is hardly any knowledge available because the respective research or innovation field is still at a very early stage. In these cases, citizens may not feel confident to discuss certain issues with other citizens and/or to exchange their views with experts. Plenty of third sector actors are not experienced or 
equipped for engaging with research and research and innovation policy. Low levels of topic-related knowledge and lack of competent individuals or personnel to actively and effectively take part in an engagement process can deter them from becoming involved [17]. Citizens in particular may think they lack the communicative skills to participate in dialogues and discussions. When engagement includes the use of technical devices such as web-based tools, microphones for making one's own contributions, or video/audio recording, and when citizens are not familiar with such devices, this can have an additional discouraging effect. It is especially likely in the case of less privileged individuals. Societal engagement and political participation generally tend to be dominated by people of higher socio-economic status, such as the middle classes. Depending on how it is designed, societal engagement in research and in research and innovation policy bears the risk of perpetuating the peripheral role of the less privileged. When self-recruitment is adopted for selection of participants, and when the citizens are invited to deal with highly abstract and unpopular topics, when the engagement is only about exchange of arguments (and not for instance, about exchange of personal experiences and views), these are the marginalized groups such as migrants, the socially vulnerable, and the less educated who are most likely to be deterred from getting involved.

A huge problem that can be identified is that third sector actors may not get involved in research projects because they have little or no understanding of the research system in their country and at the EU level. They may not be aware of research funding opportunities for third sector actors or they may have no knowledge of how to (jointly) set up a project proposal and what is required from beneficiaries of publicly funded research in terms of research and administrative tasks and responsibilities [18].

One possibility to deal with the indicated problems is to try to embed engagement more widely into the education system. Teaching on civic engagement and engagement in research and in research and innovation policy can be included in classes on science, citizenship or similar subjects in secondary schools. Building capacities and developing innovative ways of connecting science to society is a priority under Horizon 2020 [19]. Knowledge of science is integral to preparing our population to be actively engaged and responsible citizens, creative and innovative, able to work collaboratively, and fully aware of and conversant with the complex challenges that the society needs to face. It helps us to explain and understand our world, to guide technological development and innovation, and to forecast and plan for the future [20]. It can promote citizens' awareness, interest, and willingness to be engaged in scientific debates from an early age and increase their confidence that they can be valuable partners in science and governance of science. Educational organizations can furthermore integrate elements of engagement into school life. They can make use for instance, of debating clubs, school parliaments or class councils in which the pupils debate, discuss and decide on topics of their choice. In addition, societal debates on research and innovation can be simulated in science classes. Use of such formats can help develop competences early on in community-building, dialogue, discussion, and participation. The Erasmus + programme of the EU could showcase examples of societal engagement in research and innovation in order to attract applications in this field. Erasmus + is the new EU programme for education, training, youth, and sport which includes (amongst others) the Lifelong Learning Programme (LLP) and the Youth in Action Programme [21]. Another helpful element can be promotion of science education. This promotion can be attempted to achieve by including principles of scientific thinking more widely in the school education curricula. When citizens have a basic understanding of the principles based on which the science works, it may appear less daunting. This may encourage greater contact with scientists. Science journalism can help explain scientific facts and findings and stimulate interest in research and innovation and thereby contribute to ensuring that societal needs and concerns feed more effectively into 
the research and innovation systems. One way to strengthen science journalism is to make it an integral part of the education of journalists at universities. Another way is to establish structures for dialogue between policy, science, and journalists [22].

Providing support through National Contact Points: The existing network of National Contact Points (NCPs) is the main structure to provide guidance, practical information, and assistance on all aspects of participation in the EU research programmes. The NCPs are established at a national level and give personalized Relevance Impact Trust Knowledge \& Skills Time \& Resources Legitimacy [23]. They could contribute to capacity-building for third sector actors by serving also as contact points for societal engagement in research. They would build up competence for offering their basic services also in relation to participatory and collaborative research, for instance, in terms of assistance in partner search or guidance on choosing relevant topics and types of action. The support of initiatives and projects involving researchers and societal actors could be explicitly included in their mandate. Opening up advisory boards to third sector organizations: Capacity-building for third sector actors can also occur through learning by doing. This can take place, for instance, through participation in committees that advise on funding programmes and policy [24].

\section{Conclusion}

Innovation is a change that leads to new quality, a new relationship, a new way of acting or a new solution. And speaking even more succinctly and settling the matter in the market realities: change, as a result of which a new service or new product is created. I will use an example: we introduce some unexpected elements to an existing set of blocks. It leads to development of a different set of blocks which better meets the current needs of users, opens up some new opportunities for builders and at the same time affects the other sets of blocks. However, this is not the case, for example, a new variant of the building, made up of known elements. It is a different way of thinking, followed by innovative actions or previously non-existing relationships [24]. Citizens and third sector actors may be more willing to get involved when they learn that special care has been taken to present balanced information, for instance through expert contributions that include diverse perspectives. Possibilities for self-learning such as interactive websites or a list of relevant web-links can meet the demands of those who wish to obtain more in-depth information and may mitigate the concerns of those who fear restricted and biased information. The more abstract and technical the issues to be dealt with in the engagement process, the more important it is to offer information in different ways.

\section{References}

1. Krajowy Punkt Kontaktowy, Nauka z udziałem społeczeństwa $i$ dla społeczeństwa. Available at: https://www.kpk.gov.pl/?page_id=10560 (2016)

2. CORDIS, Nadszedt czas na odpowiedzialne badania naukowe i innowacje (RRI) $w$ ICT. Available at: https://cordis.europa.eu/news/rcn/123625_pl.html (2015)

3. J. Wrede, Czym jest Globalne społeczeństwo obywatelskie. In: J. Miklaszewska, J. Szczepański , Filozofia polityczna po roku 1989 Teoria - historia - praktyka. Kraków: WUJ (2012)

4. M. Majorek, Pomiędzy społeczeństwem obywatelskim a obywatelskim niepostuszeństwem. Kontestacja spoleczna jako forma wspótczesnej postawy obywatelskie. In B. Krauz-Mozer, P. Borowiec, Samotność idei. Społeczeństwo obywatelskie we wspótczesnym świecie. Krakow, p.36 (2007) 
5. J. Wrede, Czym jest Globalne społeczeństwo obywatelskie. In: J. Miklaszewska, J. Szczepański , Filozofia polityczna po roku 1989 Teoria - historia - praktyka. Kraków: WUJ (2012)

6. N. Mahony, H.C. Stephansen, Engaging with the public in public engagement with research. Res. for All. 1 (1), pp. 35-51 (2017)

7. J. Millican, Social Engagement. Available at: http://arts.brighton.ac.uk/_data/assets/pdf_file/0019/6274/Social-Engagement-2.pdf. (2018)

8. J. Merrifield, Learning citizenship. IDS working paper 158. Sussex: IDS. (2002)

9. R. Putnam, Bowling alone. The collapse and revival of American community. New York: Simon and Schuster. (2000)

10. M. Teodorczyk, Wspótpraca organizacji pozarządowych z otoczeniem. Available at: http://meakultura.pl/edukatornia/wspolpraca-organizacji-pozarzadowych-zotoczeniem-1909. (2017)

11. Policies and Activities Supporting Societal Engagement in Research and Innovation. Available at: http://engage2020.eu/media/Engage2020-Policy-Brief-Issue-1_final.pdf. . (2014)

12. I. Newman, Public engagement: a dynamo of democracy. In E. Andersson, S. Bussu, H. Davis , Engage 2020. Science, Society and Engagement. An e-anthology. London, p. 27. Available at: http://engage2020.eu/media/Engage2020_withVideo.pdf. (2015)

13. S. Bussu, H. Mulder, S. Pfersdorf, R. Kuhn, G. Mbungu, L. Nierling, Public Engagement in R\&I. London: The Involve Foundation, p. 40. (2015)

14. S. Dutta, B. Lanvin, S. Wunsch-Vincent (eds.), The Global Innovation Index 2015. Effective Innovation, Policies for Development. Cornell University. (2015)

15. M. Bukowski, A. Szpor, A. Śniegocki, Potencjat i bariery polskiej innowacyjności. Warszawa: IBS. (2012)

16. S. Dutta, B. Lanvin, S. Wunsch-Vincent (eds.), The Global Innovation Index 2015. Effective Innovation, Policies for Development. Cornell University. (2015)

17. P. Adamiak, Zaangażowanie społeczne Polek i Polaków. Wolontariat, filantropia, 1\% $i$ wizerunek organizacji pozarzadowych. Stowarzyszenie Klon/Jawor, Warszawa. (2014)

18. M. Dreyer, H. Kosow, F. Dratsdrummer, Engaging Society For Responsible Research And Innovation Lowering Barriers - Innovating Policies And Practices. PROSO Project. (2018)

19. Komisja Europejska - Dyrekcja Generalna ds. Badań i Innowacji, Horizon 2020 w skrócie. Program ramowy UE $w$ zakresie badań naukowych i innowacji. Luksemburg. (2014)

20. Science education policies in the European Commission: towards responsible citizenship. Science with and for Society. Policy Brief. 2. Available at: www.sisnetwork.eu. (2016).

21. CORDIS, Responsible Research and Innovation in Higher Education Curricula. Available at: https://cordis.europa.eu/programme/rcn/665135_en.html. (2014)

22. M. Dreyer, H. Kosow, F. Dratsdrummer, Engaging Society For Responsible Research And Innovation Lowering Barriers - Innovating Policies And Practices. PROSO Project. (2018)

23. Ibid.

24. Ibid.

25. K. Charewicz-Jakubowska, Skąd się biora innowacje? Blog SWPS. Available at: https://www.swps.pl/nauka-i-badania/blog-naukowy/5897-skad-sie-biora-innowacje. (2016) 